Kirchgessner, M. (1957b). Z. Tierernähr. 12, 304.

Kirchgessner, M. (1957c). Z. Tievernähr. 12, 156.

Kirchgessner, M. (1959a). Z. Tierphysiol. 14, 165.

Kirchgessner, M. (1959b). Z. Tierphysiol. 14, 270.

Kirchgessner, M. (1959c). Z. Tierphysiol. 14, 278.

Kirchgessner, M. (1 96 1 a). Bayer. landw. $\mathfrak{7 b . 3 8 , 9 4 5 . ~}$

Kirchgessner, M. (196rb). Futter Fütter. 12, 37.

Kirchgessner, M. (1962). Z. Tierphysiol. 17, 272.

Kirchgessner, M., Friesecke, H. \& Oelschläger, W. (1962). Z. Tierphysiol. 17, 235.

Kirchgessner, M., Merz, G. \& Oelschläger, W. (1960). Arch. Tierernähr. 10, 4 14.

Kirchgessner, M., Munz, W. \& Oelschläger, W. (1960). Arch. Tierernähr, ro, I.

Kirchgessner, M. \& Oelschläger, W. (I961). Arch. Tierernähr. 11, 310.

Kirchgessner, M., Oelschläger, W. \& Munz, W. (1960). Z. Tierphysiol. 15, 32 I.

Kirchgessner, M. \& Weser, U. (1963). Z. Tierphysiol. 18, 181.

Kirchgessner, M. \& Weser, U. (1964). Z. Tierphysiol. 19. (In the Press.)

Kirchgessner, M., Weser, U. \& Friesecke, H. (1963). Z. Tierphysiol. 18, 239.

Kirchgessner, M., Weser, U., Ftiesecke, H. \& Oelschläger, W. (1963). Z. Tierphysiol. 18, 250.

Lewis, P. K. Jr., Hoekstra, W. G. \& Grummer, R. H. (1956). F. Anim. Sci. 15, 1265.

Lewis, P. K. Jr., Hoekstra, W. G. \& Grummer, R. H. (1957). F. Anim. Sci. 16, 578.

Lewis, P.K. Jr., Hoekstra, W. G., Grummer, R. H. \& Phillips, P. H. (1956). F. Anim. Sci. r5, 741.

Liebscher, W. (1956). Lederle-Mitteilungen, 25, I.

Mills, C. F. (1954). Biochem. $\mathcal{7} . \mathbf{5 7}, 603$.

Mills, C. F. (1955). Brit. F. Nutr. 9, 398.

Mills, C. F. (I956). Biochem. 7. 63, 190.

Newland, H. W., Ulrey, D. E., Hoefer, J. A. \& Luecke, R. W. (1956). J. Anim. Sci. 15, 250.

Newland, H. W., Ullrey, D. E., Hoefer, J. A. \& Luecke, R. W. (r958). F. Anim. Sci. r7, 886.

Scharrer, K. (1955). Biochemie der Spurenelemente. Berlin and Hamburg: P. Parey.

Schreier, K., Kretz, W. \& Yang, R. (1957). Naturwissenschaften, 44, 184.

Schultze, M. O., Elvehjem, C. A. \& Hart, E. B. (r934). F. biol. Chem. ro6, 735.

Tompsett, S. L. (1940). Biochem. F. 34, 96 I.

Weser, U. \& Kirchgessner, M. (1964a). Landw. Forsch. 17. (In the Press.)

Weser, U. \& Kirchgessner, M. (r964b). Z. Tierphysiol. rg. (In the Press.)

Wöhlbier, W. \& Kirchgessner, M. (1957a). Landw. Forsch. ro, 240.

Wöhlbier, W. \& Kirchgessner, M. (1957b). Z. Tierernähr. I2, I43.

\title{
Factors which affect the availability of magnesium
}

\author{
By A. D. CARE, Rowett Research Institute, Bucksburn, Aberdeen
}

The incidence of hypomagnesaemia in ruminants has stimulated interest in the study of magnesium absorption from the alimentary tract. Under normal circumstances, the absorption of $\mathrm{Mg}$ is far from complete, so that the substantial endogenous excretion of $\mathrm{Mg}$ into the digestive tract which occurs in ruminants (Storry, 196r) can be a serious drain on the Mg reserve of the animal under conditions of impaired $\mathrm{Mg}$ absorption. Since man secretes relatively less saliva and intestinal juice than ruminants he is better equipped to exist on low $\mathrm{Mg}$ intakes. However, if absorption is impaired, as in the malabsorption syndrome, a negative $\mathrm{Mg}$ balance and hypomagnesaemia are often found (Hanna, Harrison, MacIntyre \& Fraser, 1960).

The simplest way to account for endogenous $\mathrm{Mg}$ is to assume that it is secreted into the digestive tract distal to the absorptive region. However, Care and van't Klooster (1964) have observed in the sheep that under normal dietary conditions the 
proximal site of net $\mathrm{Mg}$ absorption is the mid-ileum. Field (I96I) has reached a similar conclusion. Moreover, in the rat Chutkow (1964a,b) has shown that most net absorption of $\mathrm{Mg}$ occurs in the colon whereas most of the endogenous secretion of $\mathrm{Mg}$ occurs in the proximal gut. It would thus seem more appropriate to use the model shown in Fig. I for Mg transfer between the digestive tract and the extracellular fluid (Care, 1964 ). In this model, endogenous faecal $\mathrm{Mg}$ is derived from $\mathrm{Mg}$ secreted into the digestive tract, and it is assumed that the fraction of digestive juice $\mathrm{Mg}$ absorbed is the same as that absorbed from the food.

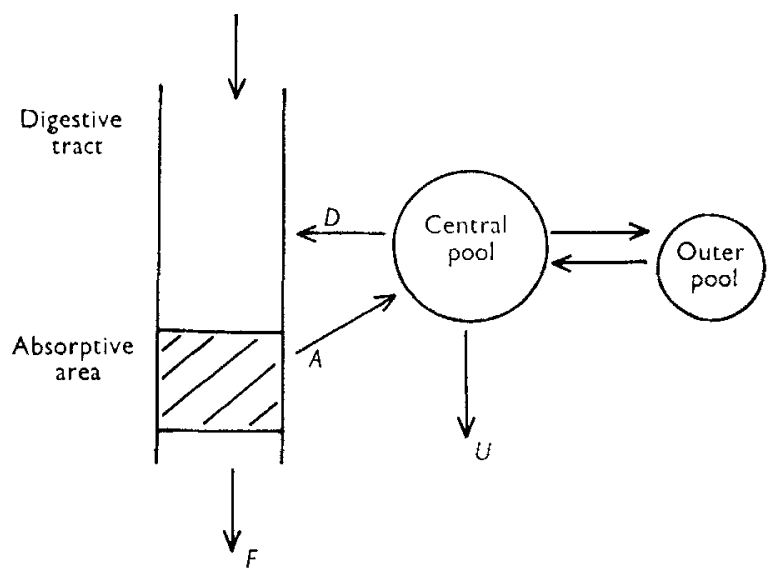

Fig. r. Scheme of magnesium metabolism. $U$ represents urinary excretion of $\mathrm{Mg}$. Other symbols are defined on p. Ior.

True availability of $\mathrm{Mg}$ may then be defined as the fraction of the total $\mathrm{Mg}$ presented to the absorptive area of the digestive tract that is absorbed. Since the digestive juice $\mathrm{Mg}$ is expected to vary with the type and quantity of the diet, the endogenous excretion in the starved animal cannot be used to calculate that proportion of the $\mathrm{Mg}$ in various foods that is unabsorbed. The true availability of $\mathrm{Mg}$ in hay has been estimated by the isotope dilution method (Macdonald, Care \& Nolan, r959) or by the double-isotope method (Field, 1959) and good agreement obtained. Simesen, Lunaas, Rogers \& Luick (I962) have also measured the true availability of $\mathrm{Mg}$ in the diets of cows and calves by the use of the isotope dilution method. In this method, the $\mathrm{Mg}$ pools within the body are labelled with ${ }^{28} \mathrm{Mg}$ to a uniform specific activity and measurements made of the specific activities of plasma and faeces. It is assumed that the body does not discriminate between ${ }^{28} \mathrm{Mg}$ and stable $\mathrm{Mg}$, that the specific activity of the secreted $\mathrm{Mg}$ is the same as that of the plasma at the time of secretion, that the ingested $\mathrm{Mg}$ mixes homogeneously and exchanges with the $\mathrm{Mg}$ of the digestive juices, and that absorption takes place subsequently 
from this mixture. Thus, the faeces are the unabsorbed residue of this mixture and have the same specific activity. Let

Specific activity of the plasma

Specific activity of the faeces

$$
\begin{aligned}
& =\alpha, \\
& =\beta,
\end{aligned}
$$

(corrected for delay in formation)

${ }^{28} \mathrm{Mg}$ secreted into the digestive tract per day $\quad=R$,

Stable Mg secreted into the digestive tract per day $=D$,

True availability of $\mathrm{Mg}$

Daily endogenous faecal $\mathrm{Mg}$ excretion

$=V$,

Daily dietary intake of $\mathrm{Mg}$

$=E$, where $E=D(\mathrm{I}-V)$,

$=I$,

Daily total faecal excretion of $\mathrm{Mg}$

$=F$.

Then, specific activity of faecal $\mathrm{Mg}$,

$$
\beta=\frac{R}{F}(\mathrm{I}-V)
$$

and specific activity of the corresponding plasma $\mathrm{Mg}, \alpha=\frac{R}{D}$.

$$
\begin{aligned}
& \text { Thus, } \frac{D(\mathrm{I}-V)}{F}=\frac{\beta}{\alpha}, \\
& \text { i.e. } \frac{E}{F}=\frac{\beta}{\alpha}, \\
& \text { since } \beta=\frac{R}{D+I}, \quad \beta=\frac{\alpha D}{D+I} \\
& \text { or } D=\frac{\beta I}{(\alpha-\beta)} .
\end{aligned}
$$

Because some absorption of $\mathrm{Mg}$ doubtless occurs before mixing is complete, the value for $D$ as calculated here is likely to be maximal.

The true daily absorption of the food $\mathrm{Mg}$ is given by

$$
A=I+D-F \text {, }
$$

and the true availability of the food $\mathrm{Mg}$ by

$$
V=\frac{I+D-F}{I+D} .
$$

Results for two sheep, two cows and two calves are shown in Table I. The principal advantage of this treatment, in which allowance is made for digestive juice $\mathrm{Mg}$, is that it allows calculation of what is probably a physiologically meaningful estimate, $D$, whereas $E$ is physiologically ill-defined.

Storry (I96r) has estimated the daily secretion of Mg into the digestive tract of the sheep to be $190 \mathrm{mg}$, excluding contributions from the ileum, caecum and large intestine. The ileal contribution to the $\mathrm{Mg}$ secreted proximal to the absorptive region is $65 \mathrm{mg}$ (Care \& van't Klooster, 1964 ) to give a total of $255 \mathrm{mg}$ for comparison with $D$ (Table I). Any $\mathrm{Mg}$ secreted below the absorptive region can be ignored since it does not enter into the calculation of $D$. It may be seen from Table I that the true 
Table I. True availability of dietary magnesium estimated by the isotope dilution method

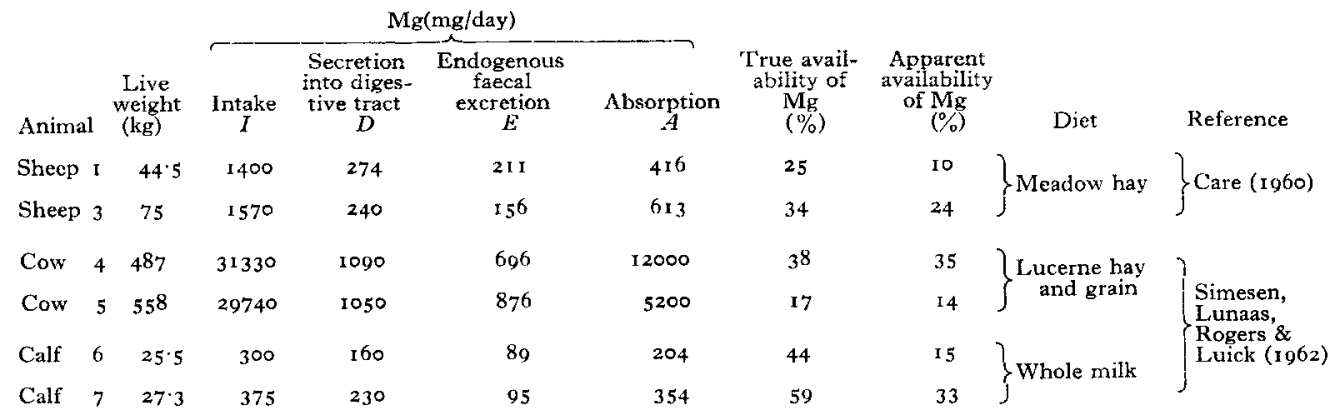

availability of dietary $\mathrm{Mg}, V$, is always greater than the apparent availability, calculated as the proportion of dietary $\mathrm{Mg}$ not appearing in the faeces, i.e. $\frac{I-F}{I}$.

In man, endogenous faecal excretion of $\mathrm{Mg}$ is extremely small (Zumoff, Bernstein, Imarisio \& Hallman, I958), so that the apparent availability of dietary $\mathrm{Mg}$ approximates to the true availability.

\section{Dietary factors which affect absorptive efficiency of $M g$}

Magnesium status of the animal. McAleese, Bell \& Forbes (196I) compared the absorption of orally administered ${ }^{28} \mathrm{Mg}$ to $3^{-5}$ month old lambs fed on either a normal or a $\mathrm{Mg}$-deficient diet for 4 weeks. They found a higher percentage absorption in the deficient group. This increase in efficiency of absorption may be a reflection of the lower plasma $\mathrm{Mg}$ concentration of the deficient group, but at least part of the effect may represent a genuine increase in absorptive efficiency of $\mathrm{Mg}$ at lower dietary intakes. Graham, Caesar \& Burgen ( 1960 ), using orally administered ${ }^{28} \mathrm{Mg}$, have shown that in man the efficiency of absorption of dietary $\mathrm{Mg}$ is greater on a low-Mg diet than on a high one. They also found that absorptive efficiency was not significantly affected by either a short-term depletion or repletion of body $\mathrm{Mg}$. In the rat, Chutkow ( $1964 b$ ) also concluded that the major regulator of $\mathrm{Mg}$ absorption is the quantity of $\mathrm{Mg}$ in the intestinal lumen rather than the nutritional requirements of the animal. The relationship between ileal concentration of $\mathrm{Mg}$ and its net absorption rate has been investigated in conscious sheep by the use of Thiry-Vella loops (Care \& van't Klooster, 1964). They showed that absorptive efficiency of $\mathrm{Mg}$ decreased with increasing $\mathrm{Mg}$ concentration in the ileum at normal plasma $\mathrm{Mg}$ concentration. A similar result was obtained by Ross ( 1962 ) using rat small intestine in vitro. Although net absorption of $\mathrm{Mg}$ does not take place from the rumen of the sheep with normal dietary Mg intake (Storry, I960), such absorption can occur when the diet is supplemented with additional Mg. In this way, the overall availability of Mg may be partially maintained (Care \& van't Klooster, I964).

Dietary calcium. There is a good deal of evidence for a common mechanism by which $\mathrm{Mg}$ and $\mathrm{Ca}$ are absorbed from the ileum in rats (Alcock \& MacIntyre, 1962), 
in sheep (Care \& van't Klooster, I964), and in man (Heaton, Hodgkinson \& Rose, 1964). This observation has been extended to include strontium (Hendrix, Alcock \& Archibald, 1963). It seems possible that the absorption of both $\mathrm{Ca}$ and $\mathrm{Mg}$ from the ileum may take place by a process of facilitated diffusion, whereas $\mathrm{Ca}$ absorption from the duodenum may be an active process which is sensitive to vitamin $D$ (Schacter \& Rosen, 1959). In contrast to its enhancement of $\mathrm{Ca}$ absorption, vitamin $\mathrm{D}$ has not been shown to have any similar effect on $\mathrm{Mg}$ absorption in either man (Wacker, Moore, Ulmer \& Vallee, 1962) or the calf (Smith, 1962).

Dietary potassium. A good deal of attention has been paid to the role of $\mathrm{K}$ as an aetiological factor in ruminant hypomagnesaemia since the diet of such animals is very high in K. Kemp, Deijs, Hemkes \& van Es (196r) concluded that the heavy application of both nitrogen and $\mathrm{K}$ to pasture reduces the apparent availability of the herbage $\mathrm{Mg}$. Kemp \& 't Hart (1958) also observed that a heavy application of potash fertilizer alone to a pasture was associated with a hypomagnesaemic response in cows put out to graze. However, when the concentration of $\mathrm{K}$ in an experimental ileal loop in vivo was raised from that found in ileal digesta on a hay diet (19 mequiv./1.) to concentrations in excess of that on a lush grass diet (33 m-equiv./1.) there was no significant difference in the net absorption rate of $\mathrm{Mg}$ from the loop (Care, 1964, unpublished). Also, if the diet of a sheep was supplemented with potassium bicarbonate and water so that the intake of these two substances became equal to that when the sheep was fed on a diet of lush grass, there was no typical hypomagnesaemic response similar to that observed in association with the grass diet (Care \& Ross, I96r, unpublished observation).

Ruminal ammonia concentration. Head \& Rook (1955) reported a correlation between a high ruminal ammonia concentration during the first few days of lush grass feeding and a decrease in serum $\mathrm{Mg}$ concentration. There was also a decrease in the urinary excretion of $\mathrm{Mg}$ which was suggested to reflect a reduction in its intestinal absorption. Subsequently, the addition of ammonium acetate, or ammonium carbonate, to the rumen of cows fed on a diet of hay and concentrates was shown to produce ruminal ammonia levels similar to those observed on a grass diet, a decrease in urinary $\mathrm{Mg}$ excretion and a moderate reduction in serum $\mathrm{Mg}$ concentration. They suggested that the hypomagnesaemia was largely due to a reduced availability of the $\mathrm{Mg}$ in lush grass. Later, Head \& Rook (1957) reported a marked decrease in the concentration of ultrafilterable $\mathrm{Mg}$ in the small intestinal digesta of sheep fed on lush grass relative to the concentration in those of sheep fed on a diet of hay and concentrates. At first, it was suggested that this was brought about by the precipitation of $\mathrm{Mg}$ as magnesium ammonium phosphate within the digesta. However, Simesen (1963) was unable to demonstrate any significant changes in either ruminal or abomasal $\mathrm{pH}$ of a cow fed on grass despite increases in ammonia concentrations in both the ruminal and abomasal fluids. Nevertheless, there was a hypomagnesaemic response and a sharp decrease in urinary $\mathrm{Mg}$ excretion. A similar finding for ruminal and abomasal $\mathrm{pH}$ has been obtained in the sheep (Hill \& Care, 1961, unpublished). Contrary to the findings of Head \& Rook (1957), Care (1964, unpublished observation) observed no significant alteration in the ultrafilterable $\mathrm{Mg}$ 
concentration of digesta obtained from either the duodenum or the mid-ileum of sheep fed on either a lush grass or a hay diet, despite the fact that the usual hypomagnesaemic response was obtained on the grass diet. It would thus seem unlikely that the reduction in availability of dietary $\mathrm{Mg}$ associated with grass-induced hypomagnesaemia is dependent on a reduction in the acidity of the abomasal digesta. Moreover, with in vitro experiments using preparations of rat small intestine, Ross (I96r) was unable to detect any influence of either $\mathrm{K}$ or ammonium ions on $\mathrm{Mg}$ transport across the intestinal wall.

Dietary sodium. Ross ( $\mathrm{r} 96 \mathrm{I}$ ) demonstrated in vitro that Mg transport across the rat intestinal wall increased with intraluminal concentration of $\mathrm{Na}$ but it has not been shown that any such effect operates in the intact animal.

Dietary phosphate and other anions. A high dietary level of phosphorus was shown to cause a negative $\mathrm{Mg}$ balance in guinea-pigs (O’Dell, Morris, Pickett \& Hogan, I957). This was due to a decreased absorption of $\mathrm{Mg}$ from the digestive tract.

However, in most other species it is probable that variation of dietary phosphate, within the limits usually encountered in practice, is unlikely to exert much effect on the availability of dietary $\mathrm{Mg}$. In some species, $\mathrm{P}$ in the form of phytic acid may serve to reduce the availability of $\mathrm{Mg}$ if suddenly added to the diet, but, in sheep, phytates are rapidly hydrolysed in the rumen (Reid, Franklin \& Hallsworth, 1947).

Ross ( $196 \mathbf{1}$ ) could find no difference in the rate of transport of $\mathrm{Mg}$ from the small intestine in vitro when either sulphate, nitrate or acetate was substituted for chloride. There may, however, be an effect in vivo since poor absorption of a particular anion would be expected to lead to relatively more fluid retention in the gut and a decreased transit time of $\mathrm{Mg}$ through its absorptive region.

\section{Endocrine effects on $M g$ absorption}

Effect of the parathyroids. During a study of $\mathrm{Mg}$ metabolism in patients with parathyroid disorders, Heaton \& Pyrah ( I $_{9} 63$ ) noted that five out of six cases of partial parathyroidectomy following primary hyperparathyroidism showed a decrease in the apparent availability of dietary Mg. In the sheep, Care \& Keynes (I964) found that total thyroparathyroidectomy resulted in a reduction in the net absorption rate of $\mathrm{Mg}$ from the ileum. The simultaneous infusion of thyroxine at a physiologically normal rate had no effect on the $\mathrm{Mg}$ absorption rate, despite the well-established hypomagnesaemic effect which was also observed. The intravenous infusion of bovine parathyroid extract to a parathyroidectomized or to an intact sheep showed first a fall in the net $\mathrm{Mg}$ absorption rate to be followed later by a return to normal levels. They suggested that this initial decrease in $\mathrm{Mg}$ absorption rate was caused by the calcitonin content of the parathyroid extract, since these extracts also produced a rapid hypocalcaemic and hypomagnesaemic response.

Effect of the adrenals. It is now well recognized that primary aldosteronism is often associated with a negative $\mathrm{Mg}$ balance and that this is reversed after removal of the tumour. Hanna \& MacIntyre (1960) showed that the administration of aldosterone to both normal and adrenalectomized rats resulted in a decrease in the 
apparent availability of the dietary $\mathrm{Mg}$. This result was confirmed in the intact sheep by Care \& Ross (1963) using deoxycorticosterone acetate instead of aldosterone.

Since in most circumstances the diet provides excessive amounts of $\mathrm{Mg}$, it seems likely that the endocrine factors function to reduce the availability of dietary $\mathrm{Mg}$ rather than to increase it. Notwithstanding the recent acceleration in research devoted to $\mathrm{Mg}$ homoeostasis, as a result of the introduction of accurate and sensitive methods for the determination of $\mathrm{Mg}$ in biological material, much still remains to be known of these factors which regulate its absorption from the digestive tract.

\section{REFERENCES}

Alcock, N. \& MacIntyre, I. (1962). Clin. Sci. 22, 185.

Care, A. D. (1960). Res. vet. Sci. 1, 338 .

Care, A. D. (1964). F. physiol. (In the Press.)

Care, A. D. \& Keynes, W. M. (1964). Proc. R. Soc. Med. (In the Press.)

Care, A. D. \& Ross, D. B. (1963). Res. vet. Sci. 4, 24.

Care, A. D. \& van't Klooster, A. H. (r 964). F. physiol. (In the Press.)

Chutkow, J. G. (1964a). F. Lab. clin. Med. 63, 71.

Chutkow, J. G. (1964b). F. Lab. clin. Med. 63, 8o.

Field, A. C. (1959). Nature, Lond., r83, 983.

Field, A. C. (1961). Brit. F. Nutr. 15, 349.

Graham, L. A., Caesar, J. J. \& Burgen, A. S. V. (1960). Metabolism, 9, 646.

Hanna, S., Harrison, M., MacIntyre, I. \& Fraser, R. (I960). Lancet, ii, 172.

Hanna, S. \& MacIntyre, I. (1960). Lancet, ii, 348.

Head, M. J. \& Rook. J. A. F. (1955). Nature, Lond., r76, 262.

Head, M. J. \& Rook, J. A. F. (1957). Proc. Nutr. Soc. 16, 25.

Heaton, F. W., Hodgkinson, A. \& Rose, G. A. (1964). Clin. Sci. 27, 3 I.

Heaton, F. W. \& Pyrah, L. N. (1963). Clin. Sci. 25, 475.

Hendrix, J. Z., Alcock, N. W. \& Archibald, R. M. (1963). Clin. Chem. 9, 734.

Kemp, A., Deijs, W. B., Hemkes, O. J. \& van Es, A. J. H. (I96I). Neth. F. agric. Sci. 9, ${ }^{3} 34$.

Kemp, A. \& 't Hart, M. L. (r958). Neth. F. agric. Sci. 5, 4.

McAleese, D. M., Bell, M. C. \& Forbes, R. M. (1961). \%. Nutr. 74, 505.

Macdonald, D. C., Care, A. D. \& Nolan, B. (1959). Nature, Lond., 184, 736.

O'Dell, B. L., Morris, E. R., Pickett, E. E. \& Hogan, A. G. (1957). F. Nutr. 63, 65.

Reid, R. L., Franklin, M. C. \& Hallsworth, E. G. (1947). Aust. vet. F. 23, 136.

Ross, D. B. (196I). Nature, Lond., r89, 840 .

Ross, D. B. (1962). F. Physiol. r6o, 417.

Schacter, D. \& Rosen, S. M. (1959). Amer. F. Physiol. 196, 357.

Simesen, M. G. (1963). Proc. int. vet. Congr. xvir. Hanover. (In the Press.)

Simesen, M. G., Lunaas, T., Rogers, T. A. \& Luick, J. R. (1962). Acta vet. scand. 3, 175.

Smith, R. H. (1962). Biochem. F. 83, 151 .

Storry, J. E. (1960). Studies on calcium and magnesium in the ruminant in relation to the aetiology of grass tetany. Ph.D. Thesis, University of Aberdeen.

Storry, J. E. (1961). Nature, Lond., 190, I 197.

Wacker, W. E. C., Moore, F. D., Ulmer, D. D. \& Vallee, B. L. (1962). F. Amer. med. Ass. 180, 161.

Zumoff, B., Bernstein, E. H., Imarisio, J. J. \& Hallman, L. (1958). Clin. Res. 6, 260.

\section{The availability of the calcium and phosphorus of plant materials for animals}

\section{By T. G. TAYLOR, Department of Physiological Chemistry, University of Reading}

The availability of calcium and phosphorus for ruminants has been reviewed recently by Hill (1962) and it is proposed, therefore, to discuss only non-ruminants in this paper, and to concentrate largely on the problem of the availability of phytate 